ISSN 0258-7122

Bangladesh J. Agril. Res. 34(3) : 473-480, September 2009

\title{
EFFECT OF FERTILIZER AND VARIETY ON THE YIELD OF SWEET POTATO
}

\author{
M.R. ALI ${ }^{1}$, D.J. COSTA ${ }^{2}$, M.J. ABEDIN ${ }^{3}$ \\ M.A. SAYED ${ }^{4}$ AND N.C. BASAK ${ }^{5}$
}

\begin{abstract}
The field experiment was conducted during the rabi season of 2005-06 in the farmer's field of Multi-location Testing (MLT) site, Melandah, Jamalpur to evaluate the performance of sweet potato varieties as well as to determine the optimum dose of fertilizer of sweet potato. Two varieties of sweet potato viz., i) BARI Sweet Potato-5 and ii) BARI Sweet Potato-7 and five fertilizer doses viz., i) Estimated fertilizer dose for average yield goal (EDI for average yield goal), ii) Integrated Plant Nutrient System (IPNS) basis fertilizer dose, iii) Fertilizer Recommendation Guide' 97, iv) Farmer's practice, and v) Control. The highest sweet potato yield was obtained from BARI SP-7 with (IPNS) basis fertilizer doses (33.9 t/ha). The lowest sweet potato yield was obtained from BARI SP-7 with control treatment. The highest gross return (112700 Tk./ha) and gross margin (10756 Tk./ha) was recorded from IPNS basis fertilizer treatment. The lowest gross return (40950 Tk./ha) and gross margin (40951) Tk./ha) was recorded from control treatment. But the cost and return analysis showed that the highest benefit cost ratio (24.95) and marginal rate of return (1452) was found from FRG/97 treatment due to lower additional cost.
\end{abstract}

Key Words: Fertilizer, IPNS, sweet potato varieties and yield.

\section{Introduction}

Fertilizer is one of the most important inputs of increasing the productivity of crops (Anon., 1997). In order to obtain good yield, modern varieties of different crops require relatively high quantity of fertilizer compared to the traditional cultivars. However, the economic condition of Banglaclesh farmers often does not support them to use required quantity of fertilizers due to its high cost. On the other hand, the organic matter content of most of the soils of Bangladesh is very low (0.8-1.8\%) as compared to desired (2.5\% and above) levels (Hossain et al., 1995). Therefore, it becomes an immense need to formulate an optimum fertilizer recommendation that would produce satisfactory yields and would maintain soil health to ensure sustainable crop production. One of the alternatives to economize the use of chemical fertilizer is to incorporate crop residues or

\footnotetext{
${ }^{1}$ Senior Scientific Officer, RARS, Jamalpur, ${ }^{2}$ Principal Scientific Officer, RARS, Jamalpur, ${ }^{3}$ Additional Agricultural Extension Officer, Jamalpur Sadar, Jamalpur, ${ }^{4}$ Monitoring and Evaluation Officer, DAE, Jamalpur, ${ }^{5}$ Senior Scientific Officer, OFRD, ARS, BARI, Mymensingh, Bangladesh.
} 
farmyard manure in combination with chemical fertilizers (Sarker et al., 1996). Bhuiya and Akanda (1982) reported that organic matter in combination with chemical fertilizer showed excellent response to rice cultivation. The Integrated Plant Nutrient System (IPNS) emphasizes the need to develop fertilizer management practices for maintenance of proper soil health. The basic concept underlying the IPNS is to provide an ideal nutrition for a crop through a proper combination of various nutrient resources and their optimum utilization along with maintenance of soil productivity. Although sweet potato is one of the important tuber crops in Bangladesh, the actual yield of this crop is lower than the potential yield. Of the various factors responsible for low yield is the lack of proper management of soil (Elias et al., 1991). Soil fertility and productivity status of medium high land in Jamalpur district where sweet potato is grown is not satisfactory. Therefore, the present study was undertaken to develop a fertilizer recommendation for sweet potato in medium high land under AEZ 9 at farmer's field and to determine the profitability of different combinations of fertilizers.

\section{Materials and Method}

The experiment was conducted at the farmer's field of Multiplication lest (MLT), site, Melandah, Jamalpur during the rabi season 2005-06 with a view to finding out the suitable variety as well as determining the optimum dose of fertilizer of sweet potato. The soil belongs to the general soil type of Non-calcarious Dark Grey Floodplain under the AEZ of Old Brahmaputra Floodplain (AEZ 9). The land was medium high with loamy to clay loam. Belore conducting the experiment, the soil sample was analyzed from Bangladesh Institute of Nuclear Agriculture (BINA), Myinensingh.

The soil was characteristically acidic ( $\mathrm{pH}$ 5.2-6.2) having organic matter of 0.75-1.28\% (low), total N 0.06-0.1\% (low), exchangeable K 0.18-0.76 me/100 g soil (medium), exchangeable Ca 1.52-1.60 me/100g soil (low), exchangeable $\mathrm{Mg}$ 1.34-4.29 me/100g soil (high), available P 7.99-11.32 ppm (low), available S 7.69-10.9 ppm (low), available Zn 1.81-5.1 ppm (medium) and available B 0.05$0.29 \mathrm{ppm}$ (low). The chemical composition of cowdung is N $1.5 \%$, P $1.0 \%$, and K 1.5\% (FRG'97).

The experiment was laid out in a randomized complete block design with six dispersed replications. There were live treatments. The description of the treatments is presented in Table 1. 
Table 1. Treatment description and nutrient rates used in the field experiment.

\begin{tabular}{|c|c|c|c|c|c|c|}
\hline \multirow[t]{2}{*}{ Treatments } & \multicolumn{6}{|c|}{ Nutrient rate $(\mathrm{kg} / \mathrm{ha})$} \\
\hline & $\mathrm{N}$ & $\mathrm{P}$ & $\mathrm{K}$ & $\mathrm{S}$ & $\mathrm{Zn}$ & CD (t/ha) \\
\hline $\begin{aligned} \mathrm{T}_{1}= & \text { Estimated mineral fertilizer dose based } \\
& \text { on the soil value for AYG }\end{aligned}$ & 72 & 52 & 85 & 7 & 1 & 0 \\
\hline $\begin{aligned} \mathrm{T}_{2}= & \text { Integrated plant. Nutrient System (IPNS) } \\
& \begin{array}{l}\text { basis fertilizer management with } \\
\text { cowdung for HYG }\end{array}\end{aligned}$ & 64 & 45 & 77 & 7 & 1 & 5 \\
\hline $\begin{aligned} \mathrm{T}_{3}= & \text { Recommended fertilizer } \\
& \text { Recommendation Guide (FRG) ‘97 }\end{aligned}$ & 70 & 15 & 35 & 10 & 1 & 0 \\
\hline $\mathrm{T}_{4}=$ Farmer's practice & 85 & 35 & 45 & & & \\
\hline $\mathrm{T}_{5}=$ Absolute control & 0 & 0 & 0 & 0 & 0 & 0 \\
\hline
\end{tabular}

Note: $\mathrm{CD}=$ Cowdung, $\mathrm{AYG}=$ Average yield goal, FRG= Fertilizer recommendation guide .

Vine of two sweet potato varieties were planted in lines on 16-18 November 2005 at the spacing of $60 \mathrm{~cm} \mathrm{x} 30 \mathrm{~cm}$. Vines of terminal and semi-matured portions were used for planting. The cutting was about $15 \mathrm{~cm}$ in length with 5-6 nodes. The unit plot size was $8 \mathrm{~m} \times 5 \mathrm{~m}$. One weeding was done at 30 days after planting (DAT). The source of NPKS and Zn were urea, TSP, MP, gypsum, and zinc sulphate. Half of urea and all other fertilizers were applied at final land preparation. Remaining urea was top-dressed in two equal splits at 30 and 55 days after transplanting (DAT). The crop was grown in rainfed condition. There was no incidence of disease and insect attack. The crop was harvested during 3-5 April 2006 at full maturity. Ten plants were randomly selected prior to harvest for collecting the data on yield attributes of sweet potato. Data on tuber yield was recorded from $6 \mathrm{~m}^{2}$ ( $\left.2 \mathrm{~m} \times 3 \mathrm{~m}\right)$ areas. Collected data were analyzed statistically and the means were separated as per Duncan's New Multiple Range Test (DMRT). The partial budget and marginal analysis of' cost of undominated fertilizer treatments were done following the method suggested by Perrin et al. (1979) and Karim and Elias (1992). Tke analysis was done considering the prices of the nutrients, products, and additional costs only.

\section{Results and Discussion}

\section{Effect of variety}

The yield and yield contributing characters of sweet potato varieties are presented Table 2. The results revealed that all most all the yield and yield contributing characters varied significantly due to varietal difference. The longer plant $(106.9 \mathrm{~cm})$ was recorded from BARI SP-5 and shorter plant $(85.4 \mathrm{~cm})$ was noted from BARI SP-7. Maximum tubers/plant (5.13) was found from BARI SP7 and minimum tubers/plant (4.10) was obtained from BARI SP-5. The higher 
average diameter of' tuber $(3.87 \mathrm{~cm})$ was recorded from BARI SP-7 and smaller one $(2.92 \mathrm{~cm})$ was found in BARI SP-5. The higher tuber wt/plant (292.0 g) was recorded from BARI SP-7 and minimum tuber wt/plant (217.3 g) was observed from BARI SP-5. In case of tuber yield, the maximum tuber yield (30.5 t/ha) was recorded from BARI SP 7 and minimum tuber yield $(24.4 \mathrm{~g}$ ) was obtained from BARI SP 5. OFRD, BARI (2006-07) reported that the highest tuber yield was obtained from BARI SP-7.

Table 2. Yield and yield contributing characters of sweet potato at MLT site, Melandah during 2005-2006.

\begin{tabular}{l|l|l|l|l|l|l}
\hline \multicolumn{1}{c}{ Treatments } & $\begin{array}{c}\text { Length of } \\
\text { vine }(\mathrm{cm})\end{array}$ & $\begin{array}{c}\text { Tubers/ } \\
\text { plant (no.) }\end{array}$ & $\begin{array}{c}\text { Length of } \\
\text { tuber }(\mathrm{cm})\end{array}$ & $\begin{array}{c}\text { Breath of } \\
\text { tuber }(\mathrm{cm})\end{array}$ & $\begin{array}{c}\text { Tuber wt/ } \\
\text { plant }(\mathrm{g})\end{array}$ & $\begin{array}{c}\text { Tuber } \\
\text { yield } \\
(\mathrm{t} / \mathrm{ha})\end{array}$ \\
\hline A. Variety & & & & & & \\
BARI SP 5 & $106.9 \mathrm{a}$ & $4.10 \mathrm{~b}$ & 10.8 & $2.92 \mathrm{~b}$ & $247.3 \mathrm{~b}$ & $24.4 \mathrm{~b}$ \\
BARI SP 7 & $85.4 \mathrm{~b}$ & $5.13 \mathrm{a}$ & 9.8 & $3.87 \mathrm{a}$ & $2.92 .0 \mathrm{a}$ & $30.5 \mathrm{a}$ \\
\hline F & $* *$ & $*$ & $\mathrm{~ns}$ & $*$ & $*$ & $* *$ \\
CV (\%) & 5.04 & 3.98 & 11.03 & 9.56 & 14.39 & 7.08 \\
\hline B. Fertilizer Level & & & & & \\
EDI for average & $103.7 \mathrm{a}$ & $4.36 \mathrm{~b}$ & $10.6 \mathrm{ab}$ & $3.55 \mathrm{ab}$ & $243.2 \mathrm{~b}$ & $25.5 \mathrm{c}$ \\
yield goal & & & & & & \\
IPNS & $100.8 \mathrm{a}$ & $5.38 \mathrm{a}$ & $11.1 \mathrm{a}$ & $3.33 \mathrm{~b}$ & $298.3 \mathrm{a}$ & $32.5 \mathrm{a}$ \\
FRG 97 & $102.4 \mathrm{a}$ & $4.28 \mathrm{~b}$ & $9.8 \mathrm{ab}$ & $3.76 \mathrm{~b}$ & $290.5 \mathrm{a}$ & $28.0 \mathrm{~b}$ \\
FP & $102.6 \mathrm{a}$ & $3.05 \mathrm{c}$ & $10.6 \mathrm{ab}$ & $3.42 \mathrm{~b}$ & $254.2 \mathrm{~b}$ & $15.8 \mathrm{e}$ \\
Control & $71.4 \mathrm{~b}$ & $2.05 \mathrm{~d}$ & $9.3 \mathrm{~b}$ & $2.90 \mathrm{e}$ & $191.3 \mathrm{e}$ & $11.7 \mathrm{e}$ \\
\hline F & $* *$ & $* *$ & $*$ & $* *$ & $* *$ & $* *$ \\
CV (\%) & 10.65 & 11.24 & 9.86 & 5.92 & 13.92 & 6.69 \\
\hline
\end{tabular}

Figures in column having similar/no letter(s) do not differ significantly.

\section{Effect of fertilizer}

The yield and yield contributing characters of sweet potato varieties differed significantly due to different fertilizer combinations (Table 2). The longest plant $(103.7 \mathrm{~cm})$ was recorded from estimated mineral fertilizer dose based on average yield goal and it was statistically similar to all the treatments except control. The control treatment produced the shortest plant $(71.4 \mathrm{~cm})$. Maximum number of tubers/plant (5.38) was found from IPNS based fertilizer treatment and it was statistically different from other treatments. Control plot produced minimum tubers/plant (2.05), the longest tuber $(11.1 \mathrm{~cm})$ was recorded front IPNS treatment and it was statistically similar to all other treatments except control treatment. Control treatment produced the smallest tuber $(9.3 \mathrm{~cm})$. The maximum 
diameter of tuber $(3.76 \mathrm{~cm})$ was recorded from IPNS treatment and it was statistically identical to EDI treatment. Control plot produced the minimum diameter of tuber $(2.90 \mathrm{~cm})$. The highest tuber wt/plant $(298.3 \mathrm{~g})$ was recorded from IPNS treatment and it was stastically similar to FRG' 97 based treatment. Minimum tuber wt/plant (191.3 g) was obtained from control treatment. The highest tuber yield (32.2 t/ha) was recorded From IPNS based treatment and it was significantly higher than all other treatments. Tke highest seed yield was recorded form Integrated Plant Nutrient System (BARI, 2000). Fertilizer Recommendation Guide '97 based fertilizer treatment produced the second highest (28.0 t/ha) tuber yield. The lowest tuber yield (11.7 t/ha) was found in control treatment.

\section{Interaction effect}

The interaction effect of sweet potato varieties and fertilizer level on yield contributing characters was statistically significant (Table 3). The longest plant $(122.4 \mathrm{~cm})$ was recorded from BARI SP-5 in combination with estimated mineral fertilize dose based on average yield goal and it was statistically similar to IPNS and farmers' practice with the same variety. Tke shortest plant $(64.8 \mathrm{~cm})$ was recorded From BARI SP-7 in combination with control treatment. The maximum tubers/plant (5.63) was found from BARI SP-7 variety in combination with IPNS based fertilizer treatment and it was statistically different from other treatments except EDI, FRG '97 in the same variety and IPNS and FRG in combination with BARI SP-5 variety. Minimum tubers/plant was produced from control plot in case of both the varieties. The longest tuber $(11.8 \mathrm{~cm})$ was recorded from BARI SP-5 in combination with IPNS treatment. Control treatment produced the shortest tuber length in both the varieties. The highest diameter of tuber $(4.49 \mathrm{~cm})$ was recorded from BARI SP-7 in combination with IPNS treatment and it was statistically significant from all other treatments except EDI treatment in the same variety. Both the varieties, tuber control fertilizer treatment produced the smallest diameter of tuber. The highest tuber wt/plant (314.67 g) was recorded from BARI SP-7 in combination with IPNS treatment and it was statistically similar to FRG '97 based treatment and IPNS, FRG ' 97 based treatment from BARI SP-5. Control plot produced minimum tuber wt/plant from both the varieties. The highest tuber yield (33.9 t/ha) was recorded from BARI SP-7 in combination with IPNS based treatment and it differed significantly from all other treatments. The same variety in combination with FRG'97 based fertilizer treatment gave the second highest (30.1 t/ha) tuber yield and it was statistically identical to IPNS based treatment from BARI SP-5. The lowest tuber yield $(11.3 \mathrm{t} / \mathrm{ha})$ was obtained from BARI SP-5 in combination with control treatment. Both the varieties under control treatment gave the lowest tuber yield. 
Table 3. Interaction effects of variety and fertilizer on the yield and yield components of sweet potato at MLT site, Melandah during 2005-06.

\begin{tabular}{ll|l|l|c|c|c|c}
\hline Interaction & & $\begin{array}{c}\text { Length of } \\
\text { vine }(\mathrm{cm})\end{array}$ & $\begin{array}{c}\text { Tubers/ } \\
\text { plant } \\
(\mathrm{no})\end{array}$ & $\begin{array}{c}\text { Length of } \\
\text { tuber } \\
(\mathrm{cm})\end{array}$ & $\begin{array}{c}\text { Breadth } \\
\text { of tuber } \\
(\mathrm{cm})\end{array}$ & $\begin{array}{c}\text { Tuber wt/ } \\
\text { plant }(\mathrm{g})\end{array}$ & $\begin{array}{c}\text { Tuber } \\
\text { yield } \\
\text { (t/ha })\end{array}$ \\
\hline BARI SP-5 & EDI & $122.4 \mathrm{a}$ & $4.10 \mathrm{bc}$ & $10.6 \mathrm{abc}$ & $2.93 \mathrm{~cd}$ & $247.33 \mathrm{c}$ & $24.4 \mathrm{c}$ \\
& IPNS & $115.4 \mathrm{ab}$ & $5.13 \mathrm{ab}$ & $11.8 \mathrm{a}$ & $2.91 \mathrm{~cd}$ & $292.00 \mathrm{a}$ & $30.5 \mathrm{~b}$ \\
& FRG’97 & $102.9 \mathrm{bc}$ & $47.33 \mathrm{abc}$ & $10.5 \mathrm{abc}$ & $3.03 \mathrm{~cd}$ & $305.33 \mathrm{a}$ & $26.0 \mathrm{c}$ \\
& FP & $116.1 \mathrm{ab}$ & $3.01 \mathrm{~cd}$ & $11.5 \mathrm{ab}$ & $3.04 \mathrm{~cd}$ & $260.00 \mathrm{c}$ & $15.2 \mathrm{~d}$ \\
& Control & $78.0 \mathrm{de}$ & $2.00 \mathrm{~d}$ & $9.3 \mathrm{c}$ & $2.67 \mathrm{~d}$ & $189.33 \mathrm{~d}$ & $11.3 \mathrm{e}$ \\
\hline BARI SP-7 & EDI & $85.0 \mathrm{~cd}$ & $4.60 \mathrm{ab}$ & $10.5 \mathrm{abc}$ & $4.16 \mathrm{a}$ & $239.00 \mathrm{c}$ & $26.7 \mathrm{c}$ \\
& IPNS & $86.2 \mathrm{~cd}$ & $5.63 \mathrm{a}$ & $10.4 \mathrm{abc}$ & $4.49 \mathrm{a}$ & $314.67 \mathrm{a}$ & $33.9 \mathrm{a}$ \\
& FRG 97 & $101.9 \mathrm{bc}$ & $4.23 \mathrm{abc}$ & $9.1 \mathrm{c}$ & $3.75 \mathrm{~b}$ & $287.67 \mathrm{a}$ & $30.1 \mathrm{~b}$ \\
& FP & $89.1 \mathrm{~cd}$ & $3.09 \mathrm{~cd}$ & $9.8 \mathrm{bc}$ & $3.79 \mathrm{~b}$ & $266.00 \mathrm{~b}$ & $16.4 \mathrm{~d}$ \\
\hline F & Control & $64.8 \mathrm{e}$ & $2.13 \mathrm{~d}$ & $9.4 \mathrm{c}$ & $3.13 \mathrm{c}$ & $193.33 \mathrm{~d}$ & $12.2 \mathrm{e}$ \\
\hline
\end{tabular}

Figures in column having similar/no letter(s) do not differ significantly.

Tabel 4. Cost and return analysis of sweet potato as affected by fertilizer levels at MLT site, Melandah during 2005-06.

\begin{tabular}{|c|c|c|c|c|c|}
\hline Treatment & $\begin{array}{c}\text { Gross return } \\
\text { (Tk./ha) }\end{array}$ & $\begin{array}{l}\text { Cost that vary } \\
\text { (Tk/ha) }\end{array}$ & $\begin{array}{c}\text { Gross margin } \\
\text { (Tk./ha) }\end{array}$ & BCR & MRR (\%) \\
\hline EDI & 89250 & 7938 & $\begin{array}{l}81312 \\
\text { Discard }\end{array}$ & 11.24 & - \\
\hline IPNS & 112700 & 8944 & $\begin{array}{l}103756 \\
\text { Discard }\end{array}$ & 12.60 & - \\
\hline FRG'97 & 98000 & 3928 & 94072 & 24.95 & 1452 \\
\hline FP & 55300 & 5518 & $\begin{array}{l}49782 \\
\text { Discard }\end{array}$ & 10.05 & - \\
\hline Control & 40950 & 0 & 41120 & - & - \\
\hline
\end{tabular}

Products were considered to calculate gross return and fertilizer cost, application and additional cost were considered to calculate variable cost.

Price of the products and inputs ( $\mathrm{Tk} / \mathrm{kg})$

Products (Tk./ha): Sweet potato $=3.5$

Inputs (Tk./kg):

Urea $=6.00, \mathrm{TSP}=15.00, \mathrm{MP}=14.00$, Gypsum $=4.00$, Zinc sulphate $=65.00$, Cowdug $=0.50$ 


\section{Cost and return analysis}

Cost and return analysis is presented in Table 4 . The highest gross return (112700 $\mathrm{Tk} / \mathrm{ha}$ ) and gross margin (103756 Tk/ha) was found in IPNS treatment. The variable cost was also higher in IPNS treatment because of additional use of cowdung. OFRD (2001) reported that variable cost in the treatment IPNS was higher because of additional cost of cowduuug. Karim and Elias (1992) pointed out that the farmers always try to maximize their returns upto the point where returns to investment are the highest as the capital is scarce. The purpose of marginal analysis is to reveal how the gross margin from investment increase as the amount of investment decreases (Perrin et al., 1989). The highest benefit cost ratio (24.95) and marginal rate of return (1452) was recorded in FRG/97 treatment. Ali et al. (2003) and BARI (2000) found the highest marginal rate of return (MRR\%) by following FRG'97. It indicates that if a farmer spends additional one hundred taka, he can get an extra income of Tk. 1452. So, BARI SP-7 along with Fertilizer Recommendation Guide' 97 based treatment is the most suitable dose for growing sweet potato in Old Brahmaputra Flood Plain Soils of Jamalpur district under AEZ 9 in Bangladesh.

\section{Conclusion}

BARI SP-7 variety in combination with FRG '97 based fertilizer dose was accepted by the farmers because this variety is high yielding and the fertilizer dose is low cost.

\section{References}

Ali M. R., M. Z. Islam, M. S. Rahman, M. A. Mannan and A. K. M. M. Rahman. 2003. Effect of fertilizer alone and in combination with mustard oilcake on the growth and yield of wheat. Bangladesh J. Prog. Sci. \& Tech. 1(2): 127-130.

Anonymous. 1997. Fertilizer Recommendation Guide. Bangladesh Agricultural Research Council, Farmgate, New Airport Road, Dhaka-1215. p22.

BARI (Bangladesh Agricultural Research Institute). 2000. Annual Report 1999-2000. Bangladesh Agril. Res. Inst., Joydebpur, Gazipur, Bangladesh. p 243.

Bhuiya, M. R. and M. S. Akanda. 1982. Effect of different sources of organic materials alone and in combination with two fertilizer levels on growth parameters and combination of rice. Bangladesh J. Agric.7(3-4): 32-39.

Elias, M., M. Hossian, J. A. Quasem, M. S. Islam and M. M. Rashid. 1991. Effect of phosphaorus fertilization on the growth and yield of potato. Bangladesh J. Agric. Res. 16(2): 153-156.

Fertilizer Recommendation Guide. 1997. Bangladesh Agricultural Research Council, Farmgate, New Airport Road, Dhaka-1215. p 185. 
Hossain, M. A., A. B. M. Salahuddin, S. K. Roy, S. Nasreen and M. A. All. 1995. Effect of green manuring on the growth and yield of transplanted aman rice. Bangladesh $J$. Agric. Sci. 22(1): 2 1-29.

Karim, M. R. and S. M. Elias. 1992. Application of partial budget technique of fertilizer response data on T. aman and mustard. Bangladesh J. Agril. Res. 17(1) : 24-28.

OFRD (On-Farm Research Division). 2001. Annual Research Report 2000-2001. Bangladesh Agricultural Research Institute, Joydebpur, Gazipur, Bangladesh. p-52.

OFRD (On-Farm Research Division). 2007. Annual Research Report 2006-2007. Bangladesh Agricultural Research Institute, Joydebpur, Gazipur, Bangladesh. pp207-21 0 .

Perrin, R. K., D. L. Winkelman, E. R. Moseardi and J. R. Anderson. 1979. Farm agronomic data on farmer's recommendations. Information Bulletin 27, CIMMYT, MEXICO.

Sarker, N. I., S. Jaman, M. S. Islam, A. Bari and T. M. Shamsuddin. 1996. Effect of chemical fertilizers and organic manure on the growth and yield of potato in NonCalcareous Grey Flood plain Soil. Progress. Agric. 7(1): 63-68. 